\title{
Comparative efficiency and capacity analysis of Waqf Agricultural Enterprises (19th century Ottoman and the 21st century Turkey: Aegean Example) ${ }^{*}$
}

\author{
Nihal Cihan Temizer ${ }^{1}$ \\ 1 Independent Researcher, Yıldız Technical University, Istanbul, TURKEY, E-mail: nihalcihantemizer@gmail.com
}

\section{Abstract}

In the study, the foundation olive groves as the foundation agricultural enterprises in the 19th century Ottoman Empire Aegean Region and the 21st century Ayvalik Waqf Olive Groves Management Directorate are examined in terms of productivity and capacity. When the Aegean Region waqf agricultural enterprises were examined in the 19th century, generally waqf olive groves were found. In addition, today's Ayvalik agricultural waqf enterprise is examined. When doing research, Ottoman Archive documents and Ayvalik Waqf Olive Groves reports are used. In the waqf olive groves; When we make a comparison on the basis of villages, today's productivity has increased three times at most in some villages, sometimes the same, sometimes less, compared to the 19th century. Although today's socio-economic conditions and technology are in a better state, there has not been a serious difference in productivity. In the Ottoman Empire, foundation agricultural enterprises were operated by the method of tax-farming. Since today's waqf agricultural enterprises are operated in a similar way to the tax farming method, we can say that olive groves are operated by modern tax-farming method

Keywords: waqf, agricultural enterprises, iltizam, productivity

Jel codes: N00, N01

* This study was completed by Nihal Cihan Temizer under the supervision of Prof. Dr. Sait Öztürk at Yıldız Technical University, Institute of Social Sciences, Department of Economics with the title "The Structure and Functioning of Waqf Agricultural Enterprises In The Ottoman Empire: The Example of the Aegean Region (19th Century)". Derived from the Doctoral dissertation advocated on.

Bu derginin içerĭ̌i Creative Commons Attribution-NonCommercial 4.0 Uluslararass Lisansialtunda lisanslanmistro.

Content of this journal is licensed under a Creative Commons Attribution-NonCommercial 4.0 International License. 


\section{INTRODUCTION}

In this article, the waqf structure of the Ottoman Empire and the Republic of Turkey, agribusiness, capacity and effectiveness have been examined and compared. First, the agriculture in the 19th century Ottoman was discussed, and the structure of agriculture and agricultural enterprises in the Ottoman Empire was analyzed. Finally, analysis was made with the documents of the Ottoman Archives of the State Archives and the reports of the Ayvalık Waqf Olive Groves Business Directorate today. The document about the 19th century the Ottoman Empire and the Republic of Turkey in the 21 st century was examined to determine productivity difference. No such comparison has been conducted in waqf agricultural enterprises before.

Firstly; Agriculture and Development is explained. After, Agricultural Enterprises, Management and Capacity of Waqf Agricultural Enterprises in Ottoman Empire and Today and Productivity Analysis of Waqf Agricultural Enterprises in the Ottoman Empire and Today are explained. It is the first study that comparises the present and Ottoman Waqf Agricultural Enterprises. In this terms, it is aimed to fill the gap in the literature.

\section{AGRICULTURE AND DEVELOPMENT}

Economic and agricultural development are closely related. While a developed agricultural sector supports economic development, a backward agricultural sector prevents development. While agricultural technology in the 18th and 19th centuries progressed in Western Europe, production and economic development increased in parallel. Despite these developments, the product surplus was limited due to the insufficient technology used in production, the trade and industry sectors could not be integrated properly, and the countries with agricultural sectors could not achieve sufficient economic development. There are two important factors in agriculture: the balance of population and economic resources, and the current state of transport technology. While the population increased in the Ottoman Empire, labor and capital were scarce, transportation technology was insufficient (Güran, 2013: 69-70).

Productivity growth in agricultural development depends on two types of technological change. First; it is to obtain more product per unit of land by developing techniques that save soil. The second is; with the development of labor-saving agricultural metho$\mathrm{ds}$, higher productivity per unit of labor is achieved. In the Ottoman Empire, the land factor was relatively abundant, but the population decreased after the 17th century due to economic and political reasons. In the middle of the 19th century, the population density became seriously low. In the second half of the 19th century, the population increased in some places due to the settlement policy and migration. As a result of low population density, cultivated land constitutes a limited area of the entire land. This situation indicates that agriculture was made in a very limited area of the Ottoman Empire in the mid-19th century. While the percentage of cultivated lands was 6.7 percent in Anatolia, it was 8.3 percent in Rumelia. In areas with high population density, the cultivated land area was also high. Although land was abundant, labor was scarce.

The capital of independent small producer family businesses, which was common in Ottoman agriculture, was also limited. Capital insufficiency is among the important problems. In an economy where land is abundant and labor and capital are scarce, technologies that aim to increase productivity by saving land or labor have not been suitable. The limited capital in the Ottoman Empire prevented the productivity of labor, and the limited productivity of the land and prevented investment in them. Therefore, the use of soil-intensive, primitive technology continued. The high transportation cost was one of the reasons for agriculture to fall behind. Transportation cost in the Ottoman Empire included a significant proportion of the money to be earned from the product (Güran, 2013: 71-77).

\subsection{Agricultural Enterprises}

The size of the agricultural enterprises is important for the agricultural economy. Large enterprises with better capital equipment can comprehend effective farming methods more easily and contribute to agricultural development. In addition, the contribution of large enterprises to the trade and industry sectors is also significant (Güran, 1998: 81).

Lands, which constitute the most important part of production resources in the Ottoman Empire, constituted the first part of the resources that provide regular income to waqf institutions (Yediyıldız, 1984: 6-7).

In the Ottoman agricultural statistics, the agricultural enterprises were divided into three, cinsidering the surface area of the lands left and cultivated, regardless of whether agricultural enterprises were family owned or not.

1. İmâlât-1 Sağîre: Small businesses with an area of less than 10 decares,

2. İmâlât-1 Mütevassita: Medium-large enterprises with a surface area of 10-50 decares and

3. İmâlât-1 Cesîme : There were large enterprises with an area of more than 50 decares.

Another important factor expressing the qualifications of agricultural enterprises has been capital equipment. These are four: 1-House, warehouse, barn, buildings 
such as poultry 2-Animals, 3-Double double riding tools

4-Earth. These capital equipment shows the technological development level of the agricultural enterprise and contribute to the production power. (Güran,1998:81-83) The agricultural sector is the market that operates under conditions closest to perfectly competitive market conditions. Therefore, it comes to mind that agricultural enterprises must create the optimal production facility scale in which they will produce at the lowest cost in the long run. The reasons why agricultural enterprises cannot change the scale of production facilities that can operate at the optimal production facility scale are as follows. Business size; shows the size of the available land and the size of the factors in production. Large businesses also have high income. Costs were lower because of more efficient use of factors in large enterprises. Fixed costs are low and productivity increase is seen in large enterprises (Dinler, 2014: 164).

Agricultural productivity level is important in the development of the economy. Product surplus in agriculture contributes significantly to the development of trade and industry segments. The product surplus in agriculture also determines the yield level, so productivity in agriculture is an important factor of agricultural development. Productivity in agriculture; It can be handled in terms of labor, capital and land. Fertility per land; The average yield obtained in various crop production branches from 1 decares of land is worth. Seed fertility; In the period where modern inputs such as machinery, industrial fertilizers and chemicals are absent in agriculture, the most important agricultural input has been seed. Calculated as the revenue per unit from seed (Güran, 1998: 94-98).

\section{MANAGEMENT AND CAPACITY OF WAQF AGRICULTURAL ENTERPRISES IN OTTOMAN EMPIRE AND TODAY}

Waqf agricultural enterprises in the Aegean region generally consist of olive groves. Olive groves are "agricultural enterprises who's with and number of trees vary depending on the location of the founder of the waqf and the wealth of the waqf, where agricultural and industrial activities are carried out together".

In addition to the production in some olive groves, workshops called vices were established to extract olive oil, and water mills were established with millstones and tools for obtaining olive oil (Öztürk, 1995: 130-131).

Before the waqf Ministry was established, waqf olive groves were operated by trustees. After the 1826 regulation, it was started to be administered by the Hümayun Waqf Ministry and the olive oil obtained was exempt from tax. After the declaration of the Tanzimat (1839), the management of the olive groves belonging to the waqfs was started to be carried out by the officials (officials collecting taxes belonging to the state). After a short while, the administration of the waqf olive groves by the officials was abolished in 1842-43 and the deadline was started to be given to the tax farming on the condition that a certain amount of olive oil was given annually (Doğan, 2007:60-61).

Aegean region waqfs; Its within starboard of Karesi. On the Starboard of Karesi; There are many waqfs and large waqfs. In Edremit and Kemeredremid, the soldiers and administrators of the sultan and household members working in the center and the provinces, or the elite of the local people, had a lot of waqf. To these waqfs; Social and economic and cultural services were carried out by connecting olive groves, vineyards, gardens, lands, as well as mufasas as an inn, bathhouse, shop, house, coffee shop, bakery, soap house, flour and olive oil mill (Armağan, 2017: 30-31). 
Table 1: Sizes of Waqf Agricultural Enterprises (Edremid- Kemeredremid-1297-1879/1880)

\begin{tabular}{|c|c|c|c|c|c|c|c|c|c|c|c|c|c|c|}
\hline & İm & lat-1 $S$ & gire $(<10 \mathrm{c}$ & donu & & $\begin{array}{r}\text { Imal } \\
\text { Mütevass } \\
\mathbf{5 0} \text { don }\end{array}$ & $\begin{array}{l}\text { at-1 } \\
\text { ita } \\
\text { lum) }\end{array}$ & $10-$ & & $\begin{array}{r}\text { alat-1 } \\
\text { do }\end{array}$ & $\begin{array}{l}\text { Cesi } \\
\text { num }\end{array}$ & me $(7$ & & \\
\hline 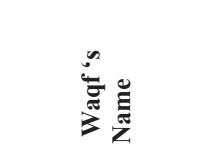 & 胥 & 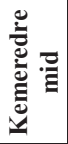 & 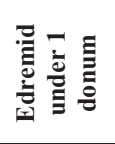 & हี & $0^{\circ}$ & 胥 & 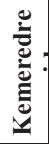 & हี & $\theta^{\circ}$ & 를 & 总 & 퐁 & $e^{\circ}$ & 苞 \\
\hline $\begin{array}{l}\text { Bezmialem Valide } \\
\text { Sultan }\end{array}$ & 60 & 18 & 12 & 90 & 52,3 & 42 & 28 & 70 & 40,7 & 3 & 9 & 12 & 6,99 & 172 \\
\hline $\begin{array}{l}\text { Mehmet Emin } \\
\text { Ağa }\end{array}$ & 24 & & 16 & 40 & 85,1 & & 1 & 1 & 2,1 & 6 & & 6 & 12,8 & 47 \\
\hline $\begin{array}{l}\text { Hace Hanife } \\
\text { Hanım }\end{array}$ & 9 & 2 & 8 & 19 & 70 & 7 & & 7 & 26 & 1 & & 1 & 4 & 27 \\
\hline $\begin{array}{l}\text { Hekimzade Sinan } \\
\text { Efendi }\end{array}$ & & & & 0 & & & & 0 & & & & 0 & & 0 \\
\hline Rabia Hanım & & & & 0 & $\mathbf{0}$ & 1 & & 1 & 100 & & & 0 & 0 & 1 \\
\hline Aliye Hanım & 3 & & & 3 & 100 & & & 0 & 0 & & & 0 & 0 & 3 \\
\hline $\begin{array}{l}\text { Sultan } \\
\text { Abdülmecid Han }\end{array}$ & & & & 0 & $\mathbf{0}$ & 3 & & 3 & 100 & & & 0 & $\mathbf{0}$ & 3 \\
\hline $\begin{array}{l}\text { Karaosmanzade } \\
\text { Hacı Hüseyin Ağa }\end{array}$ & 2 & 4 & & 6 & 20 & 4 & 5 & 9 & 30 & 8 & 7 & 15 & 50 & 30 \\
\hline $\begin{array}{l}\text { Esirizade Mehmet } \\
\text { Ağa }\end{array}$ & & & & & $\mathbf{0}$ & 2 & & 2 & 100 & & & 0 & 0 & 2 \\
\hline TOTAL & 98 & 24 & 36 & 158 & 55,4 & 59 & 34 & 93 & 32,6 & 18 & 16 & 34 & 12 & 285 \\
\hline
\end{tabular}

Source: BAO Evd 24930, BAO Evd 24925

As we can see in the table 1, when we look at the total of waqfs in Edremid and Kemeredremid, 55.4 percent are small agricultural waqf enterprises, 32.6 percent are medium-sized agricultural waqf enterprises, and 12 percent are large agricultural enterprises.

The operation of the olive groves with tax farming continued until 1926. In 1926, an amendment was made in the budget law of Waqf General Directorate. According to this regulation; The waqf olive groves would be managed by agricultural science officers and conservation officers and village guards under the management of a specialist manager who graduated from the high agricultural school, affiliated with the Field Waqf Directorate. The staff will also be assigned for the zoning and grooming of the olive groves. It is said that the olive crop will be on sale for one year, and the rental will be for two to eight years. However, for more than two years, permission of the General Directorate will be required. Tender commissions will consist of three people in total, one member from the local administration committee and one person to be elected by the municipal council under the chairmanship of the waqfs director and officer, if there is no waqfs officer, who can be deputies (Öztürk, 1995: 130-131).

Thus, we can call the current management style of the Ayvalık Agricultural Waqfs Enterprise as modern tax farming. Similar aspects of tax farming; it is usually leased for 3 years, while the local council directors etc. the issues such as being present, making contracts with high sums like an auction while rented, and auditing by the directorate.
Waqf Olive Groves Management Directorate; It started operating in 1940. The purpose of the directorate; The waqf has been the protection, protection, improvement and operation of olive groves. These olive groves are managed through the "Ayvalık Waqf Olive groves Operation Directorate".(https://www. vakifzeytinleri.gov.tr/hakkimizda)“Ayvalık Waqf Olive Groves Operation Directorate, which previously continued its activities in Ayvalık; Today, it operates on the 2nd kilometer of the Havran road in Edremit District of Balıkesir Province on an area of $58.180 \mathrm{~m} 2$, which was built in 1990. While all the olive groves of the waqf, whose management belongs to the General Directorate of Waqfs, and which have been owned by the waqf, have been leased to the business directorate and commercially operated by the business directorate, approximately $80 \%$ of them have been rented to third parties by the General Directorate of Waqfs, except for areas open to development. The olive groves that are not rented out are operated by Balıkesir Vak1flar Regional Directorate." (https://www.sayistay.gov. tr)

As seen in the table 2 where the Directorate operates; Çanakkale Province Küçükkuyu, Balıkesir Province Edremit, Havran, Burhaniye, Gömeç, Ayvalık and Dikili in İzmir. This region includes a $100 \mathrm{~km}$ coastline. Çanakkale Ayvacık District, Balıkesir Edremit, Havran. There are 1517 parcels belonging to the Waqf in Burhaniye, Gömeç and Ayvalık Districts, and 164,818 Ayvalık olives for oil varieties on 13,607 decares of land. 
Table 2: Inventory of Olive Groves Under the Savings and Control of Ayvalık Waqf Olive Groves Operation Management (2012)

\begin{tabular}{|c|c|c|c|c|c|c|c|c|c|}
\hline & \multicolumn{3}{|c|}{ General Inventory } & \multicolumn{3}{|c|}{ Controlled } & \multicolumn{3}{|c|}{ Savings } \\
\hline & $\begin{array}{c}\text { Olive } \\
\text { Groves } \\
\text { Number }\end{array}$ & $\begin{array}{c}\text { Surface } \\
\text { Area M2 }\end{array}$ & $\begin{array}{c}\text { Tree } \\
\text { Numbe } \\
\mathbf{r}\end{array}$ & $\begin{array}{c}\text { Olive } \\
\text { Groves } \\
\text { Number }\end{array}$ & $\begin{array}{c}\text { Surface } \\
\text { Area M2 }\end{array}$ & $\begin{array}{c}\text { Tree } \\
\text { Numb } \\
\text { er }\end{array}$ & $\begin{array}{c}\text { Olive } \\
\text { Groves } \\
\text { Number }\end{array}$ & $\begin{array}{c}\text { Surface } \\
\text { Area M2 }\end{array}$ & \begin{tabular}{|l}
\multicolumn{1}{c}{ Tree } \\
Numbe \\
$\mathbf{r}$
\end{tabular} \\
\hline $\begin{array}{l}\text { Küçü } \\
\text { kkuy } \\
\text { u }\end{array}$ & 187 & $\begin{array}{r}1.141 .50 \\
6,00\end{array}$ & 19.503 & 184 & $\begin{array}{r}1.135 .74 \\
0,00\end{array}$ & 19.432 & 3 & $5.766,00$ & 71 \\
\hline $\begin{array}{l}\text { Altin } \\
\text { oluk }\end{array}$ & 137 & $\begin{array}{r}1.089 .22 \\
9,00\end{array}$ & 15.013 & 135 & $\begin{array}{r}1.082 .74 \\
9,00\end{array}$ & 14.925 & 2 & $6.480,00$ & 88 \\
\hline $\begin{array}{l}\text { Zeyti } \\
\text { nli }\end{array}$ & 392 & $\begin{array}{r}3.392 .51 \\
3,00 \\
\end{array}$ & 37.773 & 382 & $\begin{array}{r}3.294 .31 \\
6,00 \\
\end{array}$ & 36.618 & 10 & $\begin{array}{r}98.197,0 \\
0 \\
\end{array}$ & 1.155 \\
\hline $\begin{array}{l}\text { Edre } \\
\text { mit }\end{array}$ & 495 & $\begin{array}{r}3.735 .26 \\
5,00\end{array}$ & 8.607 & 495 & $\begin{array}{r}3.735 .26 \\
5,00\end{array}$ & 38.607 & 0 & 0,00 & 0 \\
\hline $\begin{array}{l}\text { Burh } \\
\text { aniye }\end{array}$ & 380 & $\begin{array}{r}2.765 .42 \\
8,00\end{array}$ & 33.654 & 379 & $\begin{array}{r}2.752 .93 \\
2,00\end{array}$ & 33.568 & 1 & $\begin{array}{r}12.496,0 \\
0\end{array}$ & 86 \\
\hline $\begin{array}{l}\text { Ayva } \\
\text { lik }\end{array}$ & 84 & $\begin{array}{r}2.663 .71 \\
5,00\end{array}$ & 31.029 & 83 & $\begin{array}{r}2.660 .05 \\
4,00\end{array}$ & 30.996 & 1 & $3.661,00$ & 33 \\
\hline Dikili & 29 & $\begin{array}{r}1.542 .06 \\
3,00 \\
\end{array}$ & 12.722 & 29 & $\begin{array}{r}1.542 .06 \\
3,00 \\
\end{array}$ & 12.722 & 0 & 0,00 & 0 \\
\hline $\begin{array}{l}\text { Topla } \\
\mathrm{m}\end{array}$ & 1.704 & $\begin{array}{r}16.329 .7 \\
19,00 \\
\end{array}$ & 188.301 & 1687 & $\begin{array}{r}16.203 .1 \\
19,00 \\
\end{array}$ & $\begin{array}{r}186.86 \\
8 \\
\end{array}$ & 17 & $\begin{array}{r}126.600 \\
00 \\
\end{array}$ & 1.433 \\
\hline
\end{tabular}

Source: Ayvalık Vakıf Olive Groves Enterprises Management 2012

In the table 2, it is seen that Edremit has the most olive groves in the regions that are in the general inventory of the Ayvalık Waqf Olive Grove Management Directorate. Edremit respectively; Zeytinli, Burhaniye, Küçükkuyu, Altınoluk, Ayvalık and Dikili followed. However, the number of olive groves owned by the directorate is quite low.
When we look at the number of olive groves at the disposal of the Directorate, the highest number of olive groves was Zeytinli. Küçükkuyu, Altınoluk, Burhaniye and Ayvalık came after Zeytinli. There is no olive grove in Edremit and Dikili for the management.

Table 3:Comparison of the Number of Olive Trees and Acres of the Agricultural Waqf Enterprises Between 1880-2017

\begin{tabular}{|l|l|c|c|c|c|}
\hline Waqfs' Name & $\begin{array}{l}\text { Village } \\
\text { Name }\end{array}$ & $\begin{array}{c}\text { Donum } \\
\text { (Ottoman } \\
\text { version as } \\
\text { Today's } \\
\text { measure) }\end{array}$ & $\begin{array}{c}\text { Tree } \\
\text { Number }\end{array}$ & Donum & $\begin{array}{c}\text { Tree } \\
\text { Number }\end{array}$ \\
\hline $\begin{array}{c}\text { 1297-(1880- } \\
\mathbf{1 8 8 1 )}\end{array}$ & $\begin{array}{c}\mathbf{1 2 9 7 -} \\
\mathbf{( 1 8 8 0 -} \\
\mathbf{1 8 8 1}\end{array}$ & $\mathbf{2 0 1 7}$ & $\mathbf{2 0 1 7}$ \\
\hline $\begin{array}{l}\text { Bezmialem } \\
\text { Valide Sultan }\end{array}$ & Avc1lar & 302 & 2272 & 180 & 2247 \\
\hline $\begin{array}{l}\text { Bezmialem } \\
\text { Valide Sultan }\end{array}$ & Zeytinli & 891 & 4819 & 453 & 5242 \\
\hline $\begin{array}{l}\text { Bezmialem } \\
\text { Valide Sultan }\end{array}$ & Güre & 234 & 1688 & 123 & 1328 \\
\hline $\begin{array}{l}\text { Bezmialem } \\
\text { Valide Sultan }\end{array}$ & Kizılkeçili & 32 & 341 & 37 & 515 \\
\hline $\begin{array}{l}\text { Mehmet Emin } \\
\text { Ağa }\end{array}$ & Zeytinli & 315 & 791 & 19 & 172 \\
\hline Sultan Mecid & Avc1lar & 66 & 338 & 60 & 741 \\
\hline
\end{tabular}

Source: Ayvalık Vakıflar Olive Groves Enterprise Management, Evd 24930

In the table 3, agricultural waqf enterprises in Republic of Turkey in the 21st century and the 19th century Ottoman Empire were compared. The Ottoman donum has also been turned into the present day. While the acre of some agricultural waqf holdings decreased overall, sometimes it increased. Some have declined, while remaining almost the same. Today, in waqf olive groves compared to the Ottoman period; The number of trees per donum has increased on average.

\section{PRODUCTIVITY ANALYSIS OF WAQF AGRI- CULTURAL ENTERPRISES IN THE OTTOMAN EMPIRE AND TODAY}

2019 Ayvalık waqf Olive Groves Operation Directorate and the Ottoman waqf olive groves are compared in 1880. As a result of the comparison, in the waqf olive groves; When we make a comparison on the basis of villages, today's productivity has increased three times in some villages, sometimes the same, sometimes less, compared to the 19th century. 
Table 4:Productivity Measurement of Bezmiâlem ValideSultan and Her Annex, VakıfOlive Groves, and Today's Waqf Olive Groves under the possession of Ayvalık Waqf Agricultural Enterprises Directorate by Villages (1879/1880-2019)

\begin{tabular}{|c|c|c|c|c|c|c|}
\hline \multirow{2}{*}{$\begin{array}{l}\text { Waqf and Village Names } \\
\text { Center of Edremid }\end{array}$} & \multirow{2}{*}{$\begin{array}{l}\text { Olive } \\
\text { Tree }\end{array}$} & \multirow{2}{*}{$\begin{array}{l}\text { Olive Oil } \\
\text { Revenue } \\
\text { Takings } \\
\text { (Desti) }^{1}\end{array}$} & \multirow{2}{*}{ Kıyye } & \multirow{2}{*}{$\begin{array}{c}\text { Olive Oil Average } \\
\text { Total Kıyye Per } \\
\text { Tree }\end{array}$} & \multicolumn{2}{|c|}{$\begin{array}{l}\text { Olive Oil Average } \\
\text { Total Per Tree (Kg) }\end{array}$} \\
\hline & & & & & 1880 y1l1 & $2019 \mathrm{y}_{111^{2}}$ \\
\hline Bezmiâlem Valide Sultan & 3374 & 1630 & 9780 & 2,9 & 3,7 & \\
\hline Hace Hanife & 334 & 120 & 720 & 2,1 & 1,4 & \\
\hline Hekimzade Yusuf & 855 & 445 & 2670 & 3,1 & 2,7 & \\
\hline Mehmet Emin Ağa & 760 & 376 & 2256 & 2,9 & 3,7 & \\
\hline Total Center of Edremid & 5333 & 2611 & 15666 & 2,9 & 3,7 & 3,6 \\
\hline \multicolumn{7}{|l|}{ Villages } \\
\hline $\begin{array}{l}\text { Kadıköy-Bezmialem- } \\
\text { Mehmet Emİn Ağa }\end{array}$ & 1049 & 411 & 2466 & 2,3 & 3 & 3 \\
\hline $\begin{array}{l}\text { Araplar- Bezmialem- } \\
\text { Mehmet Emİn Ağa- } \\
\text { Esirizade Mehmet Ağa } \\
\text { Vakfi }\end{array}$ & 1299 & 330 & 1980 & 1,5 & 1,9 & \\
\hline $\begin{array}{l}\text { Zeytunlu-Bezmialem - } \\
\text { Mehmet Emin Ağa- Hacı } \\
\text { Hanife Hanım-Aliye } \\
\text { Hanım }\end{array}$ & 6717 & 1535 & 9210 & 1,4 & 1,8 & 2,8 \\
\hline Kızılbekçilu-Bezmialem & 341 & 40 & 240 & 0,7 & 0,9 & 2,4 \\
\hline $\begin{array}{l}\text { Küre-Bezmialem-Mehmet } \\
\text { Emşn Ağa- Haci Hanife } \\
\text { Hanım }\end{array}$ & 2973 & 950 & 5700 & 1,9 & 2,4 & 3 \\
\hline $\begin{array}{l}\text { Tahta-Bezmialem -Haci } \\
\text { Hanife Hanım }\end{array}$ & 1469 & 490 & 2940 & 2 & 2,5 & \\
\hline $\begin{array}{l}\text { Kulluklar-Bezmialem - } \\
\text { Mehmet Emin Ağa }\end{array}$ & 643 & 255 & 1530 & 2,3 & 2,9 & \\
\hline $\begin{array}{l}\text { Avcılar-Bezmialem-Sultan } \\
\text { Abdülhamid-Aliye Hanım }\end{array}$ & 2823 & 855 & 5130 & 1,8 & 2,3 & 3,4 \\
\hline $\begin{array}{l}\text { Dereli-Bezmialaem- } \\
\text { Mehmet Emin Ağa- Rabia } \\
\text { Hanım }\end{array}$ & 346 & 14 & 84 & 0,2 & 0,3 & \\
\hline $\begin{array}{l}\text { Bilir-Bezmialem-Aliye } \\
\text { hanım }\end{array}$ & 132 & 41 & 246 & 1,8 & 2,4 & \\
\hline $\begin{array}{l}\text { Sekviran-Bezmialem - } \\
\text { Mehmet Emin Ağa }\end{array}$ & 2497 & 960 & 5760 & 2,3 & 2,9 & 5,6 \\
\hline $\begin{array}{l}\text { Frenk-Bezmialem-Hacı } \\
\text { Hanife Hanım }\end{array}$ & 181 & 60 & 360 & 1,9 & 2,4 & \\
\hline Çıkrıkçı-Bezmialem & 155 & 77 & 462 & 2,9 & 3,7 & \\
\hline Çorak-Bezmialem & 281 & 116 & 696 & 2,5 & 3,2 & \\
\hline $\begin{array}{l}\text { Temaşalık-Mehmet Emin } \\
\text { Ağa }\end{array}$ & 181 & 42 & 252 & 1,4 & 1,8 & 5,4 \\
\hline $\begin{array}{l}\text { Çorak-1 kebir-Bezmialaem- } \\
\text { Mehmet Emin Ağa- Hacı } \\
\text { Hanife hanım }\end{array}$ & 3032 & 1352 & 8112 & 2,7 & 3,5 & \\
\hline Yenice-Bezmialem & 151 & 20 & 120 & 0,8 & 1,02 & \\
\hline Köyler Yekun & 24270 & 7548 & 45288 & 1,9 & 2,4 & \\
\hline
\end{tabular}

Source: Evd 24930, Ayvalık Vakıflar Olive Groves Enterprise Management

*Since only desti is written in the document; 1 desti $=100$ dirhams per $6 \mathrm{kye}$. If there were Edremit Deck; 1 Dremid Deck $=100$ dirhams for 9 shores. See. "In an order addressed to Midilli Minister Mustafa Ağa, one of the chiefs of the porter of the Dergâh-1 Ali; Not even a dirham of the olive oil produced in Lesbos, Yonda Island, Ayvalık, Ayazmend, Edremit and its surroundings was asked to be sold openly or secretly to the designees and miners or to foreign merchants, and the Istanbul prepared olive oils produced were immediately delivered by the Minister to Istanbul merchants. If there was excess oil outside the Istanbul arrangement, it was allowed to be sold to those who wanted it for 8 kurus, each jug for 6 shores, or according to "current-time". BOA. HH, Number: 32371, 1246 / 1830-31. Faruk Doğan, s.w. p.26

**An average of $200 \mathrm{ml}$ of olive oil comes out of 1 kilogram of olives, here the olive weight is converted into olive oil. See http://www. olive.info.tr/?p=147 02.12.2020, and 2019 data is the Average of General Waqf Olive Groves within the Scope of Ayvalik Waqf Agricultural Enterprises Directorate 
Productivity affected by social and economic events. Greece was established in 1821 after the Greek nationalism and rebellion that started in the early 19th century. This situation also affected the Greeks living in the Aegean Region. The Greeks who went to Greece with the Greek revolt brought the problem of labor shortage on the agenda. As a result of the Ottoman-Greek war in 1877-1878 and the Balkan wars, the number of immigrants who came to the Ottoman Empire increased. In the Aegean region, immigrants were employed in olive groves instead of Greeks. However, due to the inexperience of the immigrants, the efficiency could not be obtained immediately. We can also say that the reason for this is that the immigrants who replaced the Greeks did not know olive cultivation exactly. (Doğan, 2007: 49-51).

In the 19th century, 300-400 trees were required for the olive farmer to make a living. 3-5 people from olive farmers could extract 20-30 weight of oil. In general, farmers generally owned fewer olive trees and had oil in the range of 3 to 10 scales per year. Half of the olive groves in Edremid and Kemeredremid mukata were the accidents in the surrounding areas. Before olives ripen, for the olives requested by the producer in August; The animal expense used in the transportation of salt and olives to prevent them from rotting has also put the olive farmer in a difficult situation. As a result of this situation, she had to get cash from the merchant in advance.

The farmer, who could not make enough profit from the olive sales, was able to pay off his debt to the merchant only by selling the olive trees. The farmer sold a certain part of the trees to pay tax and he had very few olive trees left. Winters are very severe and the trees dry; The farmers whose livelihood is only olives, olive oil and soap faced enormous costs. Thus, they borrowed more money from the murabahacis; Those who could not pay their debts had the danger of losing their land. Olive farmers in Edremid and Kemeredremid stated that they wanted to sell their goods to the merchants in their production sites, as they are too poor to afford the cost of taking their olive oil to Istanbul. Another problem for the farmers was selem ${ }^{* * *}$ implementation. For example; five farmers signed a contract with Selem to supply 10,000 deci of olive oil for 100,000 kurus in Ayvacik district. The lenders asked for 40 kurus, not 20 kurus, for each bundle, and they were defendants. As a result of the case, it was decided to pay 20 kurus per piece. Farmers had to take the tithe proceeds to the collection centers. But; If the center is away from one day distance, the transportation fee is paid to the reaya or the transportation was given to someone else. In Ayvalık, Havran, Edremid, Kemeredremid regions, the roads were not smooth,

***Selem: Buy goods on credit with cash look: OsmanlicaTürkçe Ansiklopedik Lûgat, Ferit Develioğlu, Aydın Kitabevi,Ankara, 2015 only for camels to be transported by camels. A kilo of fat costs 8-12 cents. As a result of the complaints, the Committee of Union and Progress established olive oil collection centers and asked the producer to send their oils to this center. Establishing and operating olive oil mills also wanted large capitals. The olive farmer would take the product to the factory and squeeze the olives and obtain oil, provided that the pomace remains with the manufacturer. (Doğan, 2007: 64-70).

Primitive technology was used in the olive oil production in the Ottoman Empire. Thus, olive oil revenue has dropped significantly. As a result of the primitive technology in the mills, the oil was not tightened well and the revenue was dropped by remaining in its pulp. Due to the heavy production process, olives were salted in the warehouses for a long time and a significant portion of them rotted. Salting has also reduced the quality of the oil. The decrease in quality also caused a price decrease. Thus, the treasury also lost income. Lack of enough facilities was another challenge. For these reasons, the state stated that it should be done to find sufficient clamps and factories in the olive producing areas. September was the beginning of the olive harvest, and March harvest was completed. Olive mills have been closed until the end of March; tax farmers have decided on the opening date. In this case, producers and business owners made complaints.

The tax farmers made irregularities in this process and arbitrarily caused the mills to be closed. Thus, the mill owners also suffered losses. Olive oil factories remained open at certain times of the year just like the mills. Local councils have notified the opening time of the factories. Factories that were opened late were damaged due to reasons such as inability to tax olive oil. In some cases, olive vices were devastated. One of the reasons for this is the decrease in olive yield due to the drying of the trees due to the difficult seasonal conditions. Another factor affecting olive oil production has been wars and security problems. Greece was established in 1821 after the Greek nationalism and rebellion that started in the early 19th century. This situation also affected the Greeks living in the Aegean Region. The Greeks who went to Greece with the Greek revolt brought the problem of labor shortage on the agenda. As a result of the Ottoman-Greek war in 1877-1878 and the Balkan wars, the number of immigrants who came to the Ottoman Empire increased. In the Aegean region, immigrants were employed in olive groves instead of Greeks. However, due to the inexperience of the immigrants, the efficiency could not be obtained immediately. Also; The high number of Greeks in olive growing regions and Greek nationalism, which started to rise in the late 19th century, brought along problems. Factories remained idle because of the Greeks leaving the region. In the memorandum of 24 R. Evvel 1336 / 10.01.1918 written to 
the Ministry of Internal Affairs; it was said that olives were fertile in Ayvalık, Edremid and Aydın provinces, but the factories could not be opened due to the lack of unemployment, and in order to solve this problem, the Greeks were asked to be sent back from Balıkesir and its surroundings, where they were sent for security reasons, and only women were allowed to return. Doğan, (2007: 49-184).

Today, advanced technology is used in olive cultivation. Olive oil is extracted in factories by cold pressing technique. The roads are incomparably smooth. Premium is given to support olive producers. The waqf employs state workers in the agricultural enterprise. There is no problem like not being able to find workers. However, different problems are encountered today. Olive tree gives product one year but another year it doesn't give product. Olive amount; It is $170.000-2000.000$ tons in var years and around 40.00060.000 tons in absent years. Thus, there is a $75 \%$ reduction in production for years. In order to limit the negative effects of the absence years; It is important to breed olive species, irrigation, spraying, fertilization, modern care and support production. In Turkey, fertilizing and spraying are not enough. $92 \%$ of olive groves cannot be irrigated. In order to solve this problem, idle water sources should be used and modern irrigation should be supported. Another problem is the olive oil storage system. The tanks should have nitrogen protected stainless steel tanks. The production and sales of adulterated oil should be strictly controlled and its sale should be prohibited. Consumption of olive oil is lower than other oils, so its consumption is low. Consumption should be encouraged and studies related to this should be increased. (http://koop.gtb.gov.tr/ data/5ad06f17ddee7dd8b423eb2e/2017\%20Zeytinya $\%$ C4\%9F\%C4\%B1\%20Raporu.pdf, 17.04.2020)

As in the past, problems continue in the waqf agricultural enterprises today. When we look at the accounting records of the waqf agricultural enterprises in the Ottoman period, it is seen that sometimes profit and sometimes loss was made. However, the damage situation of the Ayvalık waqf olive groves operation has been continuing for a while. One of the most important reasons for the loss situation is the share transferred from the income to the treasury is $15 \%$. Although it was recommended to reduce this share to $1 \%$ because of the audit of the TCA, it was not. The loss situation of the Ayvalık waqf agricultural enterprise continues. The wages of workers who are waqf employees are higher than the market, which increases the cost of the Ayvalık Waqf Agricultural enterprise.
Table 5: In Ayvalık Waqf Olive Groves Belong Enterprise Management Average Olive Products Productivity Per Tree As All Or Nothing Year (2019)

\begin{tabular}{|c|c|c|c|}
\hline $\begin{array}{l}\text { Item } \\
\text { No }\end{array}$ & $\begin{array}{l}\text { County/ } \\
\text { Town }\end{array}$ & Neighborhood & $\begin{array}{c}\text { Average } \\
\text { Productivity } \\
\text { Per Tree } \\
\text { (kg/tree-year) } \\
\text { (AVERAGE.) }\end{array}$ \\
\hline 1 & $\begin{array}{l}\text { Ayvacık } \\
\text { Küçük- } \\
\text { kuyu }\end{array}$ & $\begin{array}{l}\text { Adatepe-Arıkl1-Gökçete- } \\
\text { pe-Mihl1-Nusratl1-Sa- } \\
\text { hil-Yeşilyurt }\end{array}$ & 14 \\
\hline 2 & Edremit & Narl1-Doyran & 12 \\
\hline 3 & Edremit & Altınoluk & 12 \\
\hline 4 & Edremit & Avcılar-Arıtaşı & 17 \\
\hline 5 & Edremit & Zeytinli & 14 \\
\hline 6 & Edremit & Kızılkeçili-Akçay & 12 \\
\hline 7 & Edremit & $\begin{array}{l}\text { Güre-Çamlı- } \\
\text { bel-Tahtakuşlar }\end{array}$ & 15 \\
\hline 8 & Edremit & Kadıköy-Yolören-Ortaoba & 15 \\
\hline 9 & Edremit & Merkez Tüm Mahalleleri & 18 \\
\hline 10 & Havran & Çamdibi (Şekveren) & 28 \\
\hline 11 & Havran & $\begin{array}{l}\text { Ebubekir-Temaşalık-Ka- } \\
\text { labak-Tekke-Ham- } \\
\text { ambaşı-Fazlıca-İn- } \\
\text { önü-Sarnıç-Camikebir }\end{array}$ & 27 \\
\hline 12 & Havran & $\begin{array}{l}\text { Köylüce-Mescit-Büyük- } \\
\text { dere-Kocadağ }\end{array}$ & 28 \\
\hline 13 & $\begin{array}{l}\text { Burhani- } \\
\text { ye }\end{array}$ & $\begin{array}{l}\text { Tüm Mahalleler (Pelitköy } \\
\text { Hariç) }\end{array}$ & 20 \\
\hline 14 & $\begin{array}{l}\text { Burhani- } \\
\text { ye }\end{array}$ & Pelitköy & 18 \\
\hline 15 & Gömeç & Karaağaç & 25 \\
\hline 16 & Ayvalık & \begin{tabular}{|l} 
Küçükköy-Kemal- \\
paşa-Kâzımkara- \\
bekir-Murateli-Mut- \\
liköy-Sakarya-Fethiye
\end{tabular} & 23 \\
\hline 17 & Gömeç & Keremköy & 16 \\
\hline
\end{tabular}

Source: Ayvalık Vakıflar Agricultural Enterprise Management, 08.04.2019, Prepared by: Kadir Gülpınar (Agricultural Engineer), Hayretin Ekinci (Agricultural Technician)

In the table 5 above, all the average yields on the basis of the neighborhoods are the yield average of the years when the olives are actually collected in the olive groves by the Operation Directorate.

\section{CONCLUSION}

During the Ottoman Empire period, agricultural waqf enterprises were managed by tax farming system. After the Ministry of Waqfs was established, the state increased its control over waqfs. All income and expenses were monitored from the center. Today, we can say that the management method of agricultural waqf enterprises is modern tax farming. At the same time, follow-up from the center continues today. Similar aspects of tax farming; it is usually leased for 3 years, while the local council directors etc. such as being available, contracting with those who pay high 
amounts, such as auctions when hiring, and being inspected by the directorate.

In the waqf olive groves; When we make a comparison on the basis of villages, today's productivity has increased three times at most in some villages, sometimes the same, sometimes less, compared to the 19th century. Although today's socio-economic conditions and technology are in a better state, there has not been a serious difference in productivity.

As in the past, problems continue in the waqf agricultural enterprises today. When we look at the accounting records of the waqf agricultural enterprises in the Ottoman period, it is seen that sometimes profit and sometimes loss was made. However, the damage situation of the Ayvalık waqf olive groves operation has been continuing for a while. One of the most important reasons for the loss situation is the share transferred from the income to the treasury is $15 \%$. Although it was recommended to reduce this share to $1 \%$ because of the audit of the TCA, it was not. The loss situation of the Ayvalık waqf agricultural enterprise continues. The wages of workers who are waqf employees are higher than the market, which increases the cost of the Ayvalık Waqf Agricultural enterprise.

\section{REFERENCES}

ALKIN, E. (1988). İktisadi Giriş. 4. Baskı, İstanbul: Kanaat Printing Press

ARMAĞAN, A. (2017). Kemer-Edremit Voyvodası elHâc Ali Ağa bin el-Hâc Ahmet Ağa'nın Kemer-Edremit'te Kurduğu Vakıf ve Vakfiyesi. OTAM, 42: 1-46.

Ayvalık Vakıflar Agricultural Enterprise Management Reports

DİNLER, Z. (2014). Tarmm Ekonomisi, Bursa: Ekin Publishing House

DOĞAN, F. (2007). Osmanl Devleti'nde Zeytinyă̆ı (1800-1920). Phd. Thesis, Marmara Üniversitesi Sosyal Bilimler Enstitüsü İktisat Tarihi Abd. (2007)

GÜRAN, T. (2013). 19.Yüzyılda Osmanlı Ekonomisi Üzerine Araştırmalar. İstanbul: İş Bankası Kültür Publications

GÜRAN, T. (1998), 19.Yüzyıl Osmanlı Tarımı, İstanbul: Eren Publishing House

http://www.olive.info.tr/?p=147 (Date of Access: 02
.12.2020) http://koop.gtb.gov. tr/data/5ad06f17ddee7dd8b423eb2e/2017\%20Zeytinya\%C4\%9F\%C4\%B1\%20Raporu.pdf (Date of Access: 17.04.2020)

https://www.sayistay.gov.tr (Date of Access: 03.03.2019)

https://www.vakifzeytinleri.gov.tr/hakkimizda (Date of Access: 04.04.2019)

ISLAMOGU, H., ed. (2004). The Ottoman Empire and the World-Eeconomy. Vol. 12. Cambridge University Press.

ÖZGÜVEN, A. (1983). Tartm Ekonomisi ve Politikası. İstanbul: Filiz Publishing House.

ÖZTÜRK, N. (1995). Türk Yenileşme Tarihi Çerçevesinde Vakıf Müessesesi. İstanbul: Türkiye Diyanet Vakfı Publication.

PASKALEVA, V. (1967). Osmanlı Balkan Eyaletlerinin Avrupalı Devletlerle Ticaretleri Tarihine Katkı 17001850. İÜ. İktisat Fakültesi Dergisi, 27 (1-2): 48-59.

REDHOUSE, S.J. (2011). Turkish and English Lexicon. İstanbul: Çağrı Publication

State Archives Ottoman Archive (BOA). Evd 24925, 1297-Za.22-1297.Za.26---27.10.1880-31.10.1880

State Archives Ottoman Archive (BOA). Evd 24930, 1297-Za.29---03.11.1880

State Archives Ottoman Archive (BOA). HH, Number: 32371, 1246 / 1830-31.

YEDIYILDIZ, B. (1984). XVIII Asırda Vakıfların İktisadi Boyutu. Vakıflar Dergisi, XVIII, 5-41. 